\title{
MANAGEMENT AND ADMINISTRATION
}

DOI https://doi.org/10.51647/kelm.2020.5.2.12

\section{PODSTAWOWE CECHY REGULACJI STOSUNKÓW ROLNYCH W ŚWIETLE PRZEMIAN RYNKOWYCH}

\author{
Olena Kononenko \\ młodszy pracownik naukowy Wydziału Stosunków Rolnych i Zarządzania Przyroda \\ Narodowego Centrum Naukowego „Instytut Gospodarki Rolnej” (Kijów, Ukraina) \\ ORCID ID: 0000-0002-7867-3809 \\ enkononenko@ukr.net \\ Svitlana Loiko \\ studentka Wydziatu Stosunków Rolnych i Zarządzania Przyroda \\ Narodowego Centrum Naukowego „Instytut Gospodarki Rolnej” (Kijów, Ukraina) \\ ORCID ID: 0000-0002-9605-9362 \\ svetaverbylo@ukr.net
}

\begin{abstract}
Adnotacja. Ustalono, że stosunki rolne są z natury niezwykle złożoną i wieloaspektową kategorią, która powstała w procesie długotrwałegorozwoju społecznegotakichuprawnień,jak posiadanie, użytkowanie, rozporzadzanie gruntami, masami ladowymi, a nawet poszczególnymi terytoriami. Charakteryzują się naturalnymi, ekonomicznymi, społecznymi cechami wynikającymi z wielofunkcyjności zasobów gruntów. Argumentuje się, że szczególną wagę w warunkach transformacji stosunków rolnych do warunków rynkowych gospodarki nabrały kwestie ich regulacji. Uzasadniono, że obecny mechanizm regulacji stosunków rolnych poza cechą instytucjonalną i zakresem pola regulacyjnego powinien obejmować regulacje rynkowe, państwowe, ponadpaństwowe, korporacyjne i samorządowe. Podstawą badania były ogólne naukowe i ekonomiczne metody badań, prace naukowe na temat rozwoju stosunków rolnych i cech ich regulacji, akty prawne, zasoby Internetu. Techniki abstrakcyjnologiczne pozwoliły odkryć istotę terminu „stosunki rolne”, które są modyfikowane pod wpływem transformacji rynkowej, koncepcyjnie scharakteryzować ich główne cechy, sformułować odpowiednie wnioski i określić perspektywy dalszych badań, które powinny koncentrować się na płaszczyźnie poszukiwania najnowszego modelu ich regulacji, który oprócz rynkowego $\mathrm{i}$ rządowego powinien obejmować mechanizmy regulacji korporacyjnej i samorządowej.
\end{abstract}

Słowa kluczowe: stosunki rolne, przekształcenia rynkowe, formy gospodarowania, regulacja stosunków rolnych.

\section{ESSENTIAL CHARACTERISTICS OF LAND RELATIONS REGULATION IN THE LIGHT OF MARKET TRANSFORMATIONS}

\author{
Olena Kononenko \\ Junior Research Fellow at the Department of Land Relations Nature Management \\ National Scientific Center "Institute of Agrarian Economics" (Kyiv, Ukraine) \\ ORCID ID: 0000-0002-7867-3809 \\ enkononenko@ukr.net \\ Svitlana Loiko \\ Applicant at the Department of Land Relations Nature Management \\ National Scientific Center "Institute of Agrarian Economics" (Kyiv, Ukraine) \\ ORCID ID: 0000-0002-9605-9362 \\ svetaverbylo@ukr.net
}

\begin{abstract}
It is defined that land relations are extremely complex and versatile category, which was formed in the process of a long-time public development of fundamental rights of ownership, custody, management of land plots, land masses and even separate territories. This is a natural, economic and social peculiarity which is caused by the high functionality of land resources. It is substantiated that issues about land relations in terms of their transformation in order to align with market conditions are specialy important. It is fully demonstrated that the current mechanism of land relations regulation according to institutional understanding and the scale of the regulatory field should include market, state, supranational, corporate and self-regulation. The research is based on general scientific and economic research methods, research papers on land relations development and peculiarities of their regulation, regulatory assets and Internet resources. Abstract-logic methods allowed to disclose the essence of the term "land relations", which transforms in order to meet market conditions, to characterise their main rules, to conduct appropriate conclusions and identify the prospects for further development which should focus on the search for a new model of their regulation, which, apart from the market and state regulation, would include corporate and individual regulation mechanisms.

Key words: land relations, market transformations, forms of entities management, regulation of land relations.
\end{abstract}




\title{
СУТНІСНІ ХАРАКТЕРИСТИКИ РЕГУЛЮВАННЯ ЗЕМЕЛЬНИХ ВІДНОСИН У СВІТЛІ РИНКОВИХ ТРАНСФОРМАЦІЙ
}

\author{
Олена Кононенко \\ молодиий науковий співробітник відділу земельних відносин та природокористування \\ Національного наукового цуентру «Інститут аграрної економіки» (Київ, Украӥна) \\ ORCID ID: 0000-0002-7867-3809 \\ enkononenko@ukr.net \\ Світлана Лойко \\ здобувач відділу земельних відносин та природокористування \\ Національного наукового иентру «Інститут аграрної економіки» (Київ, Украӥна) \\ ORCID ID: 0000-0002-9605-9362 \\ svetaverbylo@ukr.net
}

\begin{abstract}
Анотація. Встановлено, що земельні відносини за своєю сутністю є надзвичайно складною і багатогранною категорією, що сформувалась у процесі довготривалого суспільного розвитку таких правомочностей, як володіння, користування, розпорядження земельними ділянками, земельними масивами і навіть окремими територіями. Їм притаманні природні, економічні, соціальні особливості, зумовлені багатофункціональністю земельних ресурсів. Аргументовано, що особливої ваги в умовах трансформації земельних відносин до ринкових умов господарювання набули питання їх регулювання. Обгрунтовано, що сучасний механізм регулювання земельних відносин за інституціональною ознакою і масштабами регуляторного поля повинен включати ринкове, державне, наддержавне, корпоративне і самоврядне регулювання. Основою досліджень слугували загальнонаукові та економічні методи дослідження, наукові праці з питань розвитку земельних відносин та особливостей їх регулювання, нормативно-правові акти, ресурси Інтернету. Абстрактно-логічні прийоми дозволили розкрити сутність терміна «земельні відносини», які видозмінюються під впливом ринкових трансформацій, концептуально охарактеризувати їх основні риси, сформулювати відповідні висновки і визначити перспективи подальших розвідок, які мають зосереджуватись у площині пошуку новітньої моделі їх регулювання, що, окрім ринкового та державного, має включати механізми корпоративного і самоврядного регулювання.
\end{abstract}

Ключові слова: земельні відносини, ринкові трансформації, форми господарювання, регулювання земельних відносин.

Вступ. Соціально-економічним перетворенням, що характерні для країн з транзитивною економікою, здебільшого притаманні гострі і суперечливі трансформаційні зміни, сконцентровані у площині земельних відносин та відносин власності.

Земельні відносини - це результат тривалого суспільного, еколого-економічного поступу в наближенні до раціонального використання земельних угідь, залучення їх до господарського та економічного обороту, способів облаштування території, їі зонування та землеустрою, становлення та розвитку форм власності і господарювання. Вони характеризуються історичними, національними, соціальними, економічними, екологічними, ментальними, матеріальними, правовими та іншими особливостями реалізації функцій землі як виняткового природного ресурсу життєзабезпечення людини, основного засобу сільськогосподарського виробництва, об'єкта нерухомості, просторового базису тощо. Основу земельних відносин становлять фактори матеріального порядку: іiі кількісні та якісні виміри, місце розташування, територіальна віддаленість від мегаполісів, ключових інфраструктурних об’єктів (доріг, шляхів, меліоративного облаштування, ринків збуту, елеваторів, електричних та газомереж і т.д.), галузева приналежність тощо. Рівень розвитку земельних відносин значною мірою впливає на такі макроекономічні та соціальні показники, як ефективність сільськогосподарського виробництва, рівень сільської зайнятості, добробут сільських домогосподарств, соціальне і демографічне благополуччя на селі, продовольча та частково енергетична, екологічна й природоохоронна безпеки країни.

3 огляду на це особливої ваги набувають питання щодо форм, методів і механізмів регулювання земельних відносин, спрямованих на раціональне використання земельних угідь, їх охорону, реалізацію організаційно-інституціональних механізмів і соціально орієнтованих напрямів земельного реформування, становлення ефективних форм власності та господарювання.

Основна частина. Мета статті - розкрити економічну сутність земельних відносин та особливості їх регулювання в умовах їх трансформації до ринкових умов господарювання.

Загалом, земельні відносини за своєю сутністю є надзвичайно складною і багатогранною категорією, що сформувалась у процесі довготривалого суспільного розвитку таких правомочностей, як володіння, користування, розпорядження земельними ділянками, земельними масивами і навіть окремими територіями. Їм притаманні природні, економічні, соціальні особливості, що зумовлені багатофункціональністю земельних ресурсів.

Виняткової ваги це питання набуває в умовах зростання чисельності населення світу, що супроводжується загостренням продовольчої проблеми й зумовлює необхідність більш інтенсивного використання земельних угідь, з одного боку, та уповільнення процесів деградації грунтового покриву - 3 іншого. Це своєю чергою призводить до збільшення навантаження на наявні земельні ресурси, що досить часто є причиною зростання антропогенного навантаження на екосистеми. 
Слід зазначити, що поширений донедавна підхід, за якого земля розглядалась лише в трьох ключових модифікаціях - як «засіб виробництва, предмет праці та просторовий базис розміщення продуктивних сил» (Екологічне право, 2005: 364; Рябоконь, 2009: 83) з часом повністю себе вичерпав (Курильців, 2014: 4). Нині цілком справедливо додаються нові не менш важливі функції землі, зокрема такі як екологічна, просторова, економічна, соціально-культурна тощо. Це накладає свій відбиток на особливості регулювання земельних відносин та змушує по-новому подивитися на їх місце і роль у складній еко-соціо-економічній системі.

Загалом, згідно із Земельним кодексом України, земельні відносини - це «суспільні відносини щодо володіння, користування та розпорядження землею» (Земельний кодекс, 2001: ст. 2). Така ж точка зору, щоправда з різними доповненнями та видозмінами, здебільшого трапляється і в наукових працях.

На переконання М. Федорова, земельні відносини являють собою «суспільні відносини щодо володіння, користування, розпорядження і управління землею на державному, господарському і внутрішньогосподарському рівнях як об'єктом господарювання і засобом виробництва у сільському господарстві» (Федоров, 1998: 12).

Натомість В. Галушко, Ю. Білик, А. Даниленко пропонують розглядати земельні відносини як «відносини 3 приводу володіння, користування і розпорядження землею як основним засобом виробництва для сільськогосподарського виробництва або просторовим базисом розміщення різних об'єктів» (Формування, 2006: 8).

В. Срмоленко характеризує земельні відносини як «суспільні відносини з приводу володіння, користування і розпорядження земельними ділянками та переходу цих правомочностей до інших осіб» (Єрмоленко, 2004: 44).

Природа суспільних відносин чітко викристалізовується й у працях українських та зарубіжних дослідників значно раннього періоду. Зокрема, М. Туган-Барановський, трактуючи «земельні відносини» як систему наукових знань, указував на те, що «земельні відносини - наука про суспільні відносини у межах господарської діяльності» (Історія, 2007). Те ж стосується розкриття сутності земельних відносин у контексті розвитку національної економіки (макроекономічний рівень), що відслідковується у працях В. Рошера (Рошер, 2005), та господарської діяльності (мікроекономічний рівень), на чому наголошує П. Струве (Струве, 2001: 424).

Дещо інші підходи трапляються у працях дослідників-правознавців. Так, В. Андрейцев вказує, що визначення земельних відносин, наведене у Земельному кодексі України, є «неповним та позбавляє можливості їх адекватного і реального втілення, оскільки воно може бути застосоване тільки до однієї групи відносин відносин права власності на землю» (Андрейцев, 2007: 14).

У дослідженнях П. Кулинича йдеться, що з часом у науковій думці відбулася трансформація сутності земельних відносин, яка еволюціонувала від «відносин використання землі як різновиду нерухомого майна» до «використання землі як основного засобу виробництва у сільському та лісовому господарстві, відносин використання землі як предмета праці, відносин використання землі як операційного базису для розселення людей та розвитку виробничої і соціальної інфраструктур суспільства, а також відносин щодо охорони землі як природного ресурсу» (Кулинич, 2011: 293).

Зокрема, В. Носік розкриває сутність земельних відносин, виокремлюючи чотири їх складники й зазначаючи «урегульовані нормами та методами земельного, приватного, публічного права суспільні відносини, що виникають між суб'єктами у процесі: 1) здійснення права власності на землю українського народу; 2) державного і самоврядного регулювання земельних відносин; 3) виконання заходів з охорони і раціонального використання землі як основного національного багатства; 4) захисту суб' єктивних земельних прав та законних інтересів громадян, юридичних осіб, територіальних громад, держави» (Носік, 2006:181).

Земельні відносини здатні впливати на розвиток продуктивних сил, в одному випадку - прискорюючи економічний ріст агросектору, в іншому - навпаки, стримуючи його. Результати наукових розвідок О. Ходаківської та О. Могильного засвідчують, що найбільшу віддачу вдається отримати лише тоді, коли «рівень розвитку земельних відносин відповідає рівню та характеру розвитку продуктивних сил» (Khodakivska, 2019: 2119). Такої ж позиції дотримується і Г. Гуцуляк, який не безпідставно стверджує, що «земельні відносини є елементом виробничих відносин суспільства... грунтуючись на тій чи іншій формі власності на землю та інші засоби виробництва, земельні відносини водночас визначають ці форми, характер володіння та користування землею, ступінь і раціональність використання землі та інших засобів виробництва, впливають на розвиток продуктивних сил суспільства» (Гуцуляк, 1991: 6).

Уповільнення земельного реформування, що відбулося у період з 2000 по 2020 рр., зумовило структурні перекоси у системі аграрного устрою та форм господарювання на користь вертикально інтегрованих компаній та транснаціонального бізнесу. Такий стан призвів до уповільнення розвитку сільських територій, порушив комплексність ринкових перетворень, зумовив появу низки системних неузгодженостей щодо розвитку аграрної галузі та суміжних до неї сфер. Фактично на деякий час поза увагою держави опинились питання охорони земель, планомірної їх консолідації, раціонального використання, підвищення й розширеного відтворення родючості грунтів, розвитку меліорації, неконтрольованої концентрації земельних масивів, що поглибило прояви монополізму в земельній і аграрній сферах.

У цьому зв'язку неабиякої ваги набуває регулювання земельних відносин, у т.ч. і державні його форми, націлені на раціональне використання земельних ресурсів, їх охорону, реалізацію організаційно-інституціональних механізмів і соціально орієнтованих напрямів земельного реформування, становлення ефективних форм власності й господарювання на землі.

Загалом термін «регулювання» тлумачиться дослідниками по-різному. Він походить від латинського "regulo" і означає «упорядковувати». Економічна енциклопедія містить два визначення цього терміна. Зокрема, під ним розуміють «спосіб та механізм підпорядковувати що-небудь певній планомірній 
організації дій, упорядковувати» та «функцію управління, що забезпечує функціонування та розвиток явищ і процесів у межах заданих кількісно-якісних параметрів» (Економічна енциклопедія, 2002: 170).

За визначенням Ф. Хміль, функція регулювання являє собою «оперативний вплив», що передбачає підготовку різного роду оперативних планів, завдань та заходів, організацію процесу їх виконання, забезпечення дієвого контролю та своєчасного внесення необхідних коригувань (Хміль, 1996: 88).

Натомість Л. Бойко розглядає регулювання як одну із функцій управління, виокремлюючи ії як «спрямування діяльності об'єкта управління на досягнення встановлених цілей через вчасне усунення відхилень та коригування планів» (Бойко, 2011: 70). При цьому акцентуючи увагу на такій формі регулювання, як «державне» (Бойко, 2011: 71-72), та обмежуючись двома методами їх регулювання - організаційними та економічними (Бойко, 2011: 81).

Через об'єктивні обставини набір форм і методів регулювання економічних процесів суттєво поповнився. Так, на наше переконання, сучасний механізм регулювання економіки «за інституціональною ознакою і масштабами регуляторного поля включає ринкове, державне, наддержавне, корпоративне регулювання» (Ходаківська, 2015: 61). Поглиблюючи такі класифікаційні підходи, М. Мартинюк виокремлює такі форми регулювання, як: державне регулювання, ринкове саморегулювання, самоврядне регулювання, корпоративне та наддержавне регулювання (Мартинюк, 2016: 11). Надаючи при цьому великої ваги самоврядному регулюванню, що актуалізується в процесі територіальної реформи та передбачає добровільне об'єднання територіальних громад і супроводжується децентралізацією владних повноважень, у т.ч. і щодо управління земельними ресурсами. Одночасно він наголошує, що «земельні ресурси $є$ національним багатством, у зв'язку з чим допустити дію у сфері земельних відносин виключно лише ринкового механізму або навіть його синтезу із самоврядним регулюванням не можна. Цілком правомірно, що держава вимушена формувати відповідні інститути, що прямо чи опосередковано впливатимуть на поведінку різних суб'єктів земельних правовідносин» (Мартинюк, 2016: 12). Таким чином, вказуючи на необхідність синтезу ринкового, самоврядного та державного регулювання, спроможних забезпечити досяжний синергетичний ефект та подолати наявні інституційні, соціальні, екологічні та еколого-економічні проблеми у земельній сфері.

Важливе місце у регулюванні земельних відносин належить державному регулюванню, що є «формою цілеспрямованого впливу держави через систему економічних, правових і адміністративних методів 3 метою забезпечення або підтримки тих чи інших економічних процесів, створення сприятливих умов для їх розвитку» (Осовська, 2007: 67-68). Ефективним та результативним таке регулювання зможе буде у разі, якщо чітко грунтуватиметься на основоположних принципах державної регуляторної політики, якими є: «принцип доцільності, адекватності, ефективності, збалансованості, передбачуваності, прозорості та врахування громадської думки» (Про засади державної..., : 2004) (табл. 1), та відповідатиме національним інтересам та суспільним потребам.

Таблиця 1

Принципи державного регулювання земельних відносин

\begin{tabular}{|l|l|}
\hline \multicolumn{1}{|c|}{ Принцип } & \multicolumn{1}{|c|}{ Основний зміст принципу та його характеристика } \\
\hline Доцільності & $\begin{array}{l}\text { обгрунтована необхідність державного регулювання господарських відносин з метою } \\
\text { вирішення наявної проблеми }\end{array}$ \\
\hline Адекватності & $\begin{array}{l}\text { відповідність форм та рівня державного регулювання господарських відносин потребі } \\
\text { у вирішенні наявної проблеми та ринковим вимогам з урахуванням усіх прийнятних } \\
\text { альтернатив }\end{array}$ \\
\hline Ефективності & $\begin{array}{l}\text { забезпечення досягнення внаслідок дії регуляторного акта максимально можливих } \\
\text { позитивних результатів за рахунок мінімально необхідних витрат ресурсів суб’єктів } \\
\text { господарювання, громадян та держави }\end{array}$ \\
\hline Збалансованості & $\begin{array}{l}\text { забезпечення у регуляторній діяльності балансу інтересів суб’єктів господарювання, } \\
\text { громадян та держави }\end{array}$ \\
\hline Передбачуваності & $\begin{array}{l}\text { послідовність регуляторної діяльності, відповідність ії цілям державної політики, а також } \\
\text { планам з підготовки проєктів регуляторних актів, що дозволяє суб’єктам господарювання } \\
\text { здійснювати планування їхньої діяльності }\end{array}$ \\
\hline $\begin{array}{l}\text { Прозорості та врахування } \\
\text { громадської думки }\end{array}$ & $\begin{array}{l}\text { відкритість для фізичних та юридичних осіб, їх об’єднань дій регуляторних органів на } \\
\text { всіх етапах їхньої регуляторної діяльності, обов’язковий розгляд регуляторними органами } \\
\text { ініціатив, зауважень та пропозицій, наданих у встановленому законом порядку, фізичними та } \\
\text { юридичними особами, їх об’єднаннями, обов’язковість і своєчасність доведення прийнятих } \\
\text { регуляторних актів до відома фізичних та юридичних осіб, їх об’єднань, інформування } \\
\text { громадськості про здійснення регуляторної діяльності. }\end{array}$ \\
\hline $\begin{array}{l}\text { Джерело: складено за даними (Про засади державної..., 2004) (відповідно до Закону України «Про засади держсавної регуля- } \\
\text { торної політики у сфері господарської діяльності») }\end{array}$
\end{tabular}

Здебільшого державне регулювання тлумачиться як «форма цілеспрямованого впливу держави через систему економічних, правових і адміністративних методів 3 метою забезпечення або підтримки тих чи інших економічних процесів, створення сприятливих умов для їх розвитку» (Жук, 2008: 735; Загородній, 2007: 758; Осовська, 2007: 67). Наукові підходи до розкриття сутності державного регулювання економіки наведено у таблиці 2. 
Систематизація наукових підходів до визначення сутності державного регулювання економіки

\begin{tabular}{|c|c|}
\hline Автори & Основний зміст дефініції державного регулювання економіки та її характеристика \\
\hline С. Шишкин & $\begin{array}{l}\text { Сукупність заходів економічного, правового та організаційного впливу на економіку, в } \\
\text { т.ч. шляхом державної підтримки і захисту суб’єктів підприємницької діяльності, а також } \\
\text { державного контролю за дотриманням законодавства суб’єктами такої діяльності }\end{array}$ \\
\hline $\begin{array}{l}\text { О. Лазор, О. Лазор; } \\
\text { С. Мельник; А. Спиркин }\end{array}$ & $\begin{array}{l}\text { Система типових заходів законодавчого, виконавчого і контрольного характеру, що } \\
\text { здійснюються компетентними державними органами з метою покращення, стабілізації і } \\
\text { пристосування діючої ринкової системи до наявних умов }\end{array}$ \\
\hline А. Діброва & $\begin{array}{l}\text { Опосередкований цілеспрямований управлінський вплив на процеси відтворення в галузі } \\
3 \text { метою забезпечення цілей державної аграрної політики }\end{array}$ \\
\hline $\begin{array}{l}\text { В. Гриньова, Н. Новікова; } \\
\text { Б. Райзберг, Л. Лозовський, } \\
\text { Е. Стародубцева }\end{array}$ & $\begin{array}{l}\text { Втручання державних органів влади за допомогою різних методів та інструментів у } \\
\text { розвиток основних економічних процесів з метою забезпечення позитивних соціально- } \\
\text { економічних результатів чи попередження, придушення несприятливих явищ }\end{array}$ \\
\hline $\begin{array}{l}\text { В. Кушлина, Н. Волгина; } \\
\text { Д. Стеченко; Л. Швайка }\end{array}$ & $\begin{array}{l}\text { Функція державного управління економікою, що націлена на реалізацію комплексу } \\
\text { заходів держави, спрямованих на скерування поведінки товаровиробника в напрямі, } \\
\text { необхідному для досягнення поставлених органами державної влади цілей }\end{array}$ \\
\hline М. Буров & $\begin{array}{l}\text { Цілеспрямоване втручання в дію ринкових законів для забезпечення їх ефективного } \\
\text { функціонування і досягнення певних соціально значимих результатів }\end{array}$ \\
\hline О. Могильний & $\begin{array}{l}\text { Економіко-нормативний вплив на процеси розвитку з метою адаптації суб’єктів } \\
\text { господарювання до зміни макроекономічних параметрів країни, усунення дестабілізуючої } \\
\text { дії кон’юнктурних і сезонних цінових коливань аграрного ринку, а також пом’якшення } \\
\text { природно-кліматичних, екологічних та інших специфічних для галузі ризиків }\end{array}$ \\
\hline В. Жушман & $\begin{array}{l}\text { Економічний вплив держави на виробництво, переробку і реалізацію } \\
\text { сільськогосподарської продукції, сировини і продовольства, а також виробничо-технічне } \\
\text { обслуговування і матеріально-технічне забезпечення агропромислового виробництва }\end{array}$ \\
\hline М. Чечетов, І. Жадан & $\begin{array}{l}\text { Відповідний механізм, або сукупність інститутів, форм, методів та інструментів, за } \\
\text { допомогою яких держава впливає на суб’єктів господарювання і ринкову кон’юнктуру } 3 \\
\text { метою створення конкурентних умов для їх функціонування та розв’язання соціально- } \\
\text { економічних проблем суспільства. }\end{array}$ \\
\hline
\end{tabular}

Джерело: складено на основі огляду наукової літератури

Таким чином, слід зазначити, що державне регулювання у науковій та навчальній літературі розглядається у двох основних різновидах. Перший як процес, другий - як механізм (система) регулювання. Однак і в першому випадку, і в другому державне регулювання забезпечить очікуваний ефект у тому разі, якщо зможе поєднати інституційно-правові, організаційні та економічні методи, включаючи й такі його форми, як пряма і непряма державна підтримка та поміркована політика протекціонізму.

Сучасна модель земельних відносин, що має місце в Україні, характеризується надконцентрацією земельних угідь у невеликого кола осіб, поглибленням сировинної експлуатації галузі, стрімким збільшенням рівня сільського безробіття, наявністю структурних перекосів у вирощуванні сільськогосподарських культур $з$ наданням пріоритету високомаржинальним видам (Khodakivska, Mohylnyi, 2018). Доволі часто це призводить до виснаження грунтового покриву та супроводжується ігноруванням частиною суб'єктів агрогосподарювання соціальних проблем розвитку села та сільських територій. Така ситуація зумовлює нагальну потребу у перегляді наявних форм, методів і способів регулювання земельних відносин, надаючи пріоритет тим із них, які спроможні забезпечити збалансований еко-соціо-економічний розвиток сектору (Ходаківська, Левек, 2018).

Ключова відмінність сучасної української моделі земельних відносин полягає у тому, що поряд 3 малими та середніми формами господарювання працюють досить великі за розміром землекористувань і капіталу агроструктури, які здебільшого характеризуються вертикальними зв'язками та яким властиві процеси злиття, поглинання, об’єднання, придбання та переуступки корпоративних прав тощо. Внаслідок цього велика кількість малих і середніх господарств формально та неформально опинилися у підпорядкуванні агрохолдингових формувань. Нині під контролем агрохолдингових структур перебуває понад 6000 сільськогосподарських підприємств (Лупенко, 2013).

Такі тенденції стали можливими через критичну відсутність державного контролю та неефективність державного регулювання земельних відносин. Такий стан справ нині загрожує існуванню малих і середніх форм агрогосподарювання, які виконують важливі функції щодо соціального й економічного розвитку сільських територій та сільської поселенської мережі.

Висновки. Беззаперечно, що втручання держави у господарські процеси має бути зведене до мінімуму. Однак очевидно, що для розв’язання таких проблем, як екологічні та соціальні, їі роль $є$ вкрай необхідною та суспільно значимою. Без належного державного регулювання досить складно урегулювати й такі негативні економічні прояви, як монополізація ринків та ресурсів, безробіття, трудова міграція тощо. Як показує практика, забезпечення прозорих, екологоощадних, соціально орієнтованих земельних відносин неодмінно потребує помірного державного втручання, а відповідно й державного регулювання. У такому аспекті надважливо досягнути балансу між державним втручанням та ринковим саморегулюванням. При цьому 
свавільне втручання в господарську діяльність землекористувача є недопустимим та таким, що суперечить ключовим засадам вільної ринкової економіки та основам теорії сталого розвитку.

\section{Список використаних джерел:}

1. Андрейцев В.І. Земельне право і законодавство суверенної України. Актуальні проблеми практичної теорії. 2-ге вид., випр. Київ : Знання, 2007. 445 с.

2. Бойко Л.М. Регулювання земельних відносин у сільському господарстві : монографія. Київ : ННЦ IAE, 2011. 316 с.

3. Буров М.П. Система регулирования экономического взаимодействия регионов : монография. Москва : Издательско-торговая корпорация «Дашков и К», 2008. 320 с.

4. Государственное регулирование рыночной экономики: учебник / под ред. Кушлина В.И., Волгина Н.А. Москва : Экономика, 2001. 735 c.

5. Гриньова В.М., Новікова Н.М. Державне регулювання економіки : навчальний посібник. Харків : Видавничий Дім «Інжик», 2004. 756 с.

6. Гуцуляк Г.Д. Земельно-ресурсний потенціал Карпатського регіону. Львів : Світ, 1991.152 с.

7. Діброва А.Д. Державне регулювання сільськогосподарського виробництва: теорія, методологія, практика. Київ : ВПД «Формат», 2008. 488 с.

8. Екологічне право України. Академічний курс : підручник / За заг. ред. Ю.С. Шемшученка. Київ : ТОВ «Видавництво «Юридична думка», 2005. 848 с.

9. Економічна енциклопедія : у 3-х т. Т. 3 / редкол.: С.В. Мочерний (відп. ред.) та ін. Київ : Академія, 2002. 952 с.

10. Срмоленко В. Земельні ресурси в майновому обороті. Право Украӥни. 2004. № 6. С. 43-46.

11. Жук И.Н. Управление : словарь-справочник. Москва : Анкил, 2008. 1024 с.

12. Жушман В.П. Аграрне право та законодавство України : навчально-практичний посібник. Харків : ТОВ «Одіссей», 2004. $688 \mathrm{c}$.

13. Загородній А.Г., Вознюк Г.Л. Фінансово-економічний словник. Київ : Знання, 2007. 1072 с.

14. Земельний кодекс України від 25.10.2001 p. № 2768-III. URL: http://zakon4.rada.gov.ua/laws/show/2768-14.

15. Історія економічних вчень (Сучасна економічна думка) : навчальний посібник. Вид 3-тє, стереотипне / за ред. Мочерного С.В. Львів : Новий Світ, 2007. 488 с.

16. Кулинич П.Ф. Правові проблеми охорони і використання земель сільськогосподарського призначення в Україні : монографія. Київ : Логос, 2011. 688 с.

17. Курильців Р.М. Поняття та сутність мультифункціонального землекористування як парадигми політики інтегрованого управління землекористуванням. Землеустрій, кадастр і моніторинг земель. 2014. № 1-2. С. 4-10.

18. Лазор О.Д., Лазор О.Я. Місцеве управління: поняття, терміни, визначення : словник-довідник. Київ : Дакор, 2006.352 с.

19. Лупенко Ю.О., Кропивко М.Ф. Агрохолдинги в Україні та посилення соціальної спрямованості їх діяльності. Економіка АПК. 2013. № 7. С. 5-20.

20. Мартинюк М.П. Теоретичні засади регулювання земельних відносин в Україні. Економіка АПК. 2016. № 7. С. 10-15.

21. Мельник С.А. Управління регіональною економікою : навчальний посібник. Київ : КНЕУ, 2000. 124 с.

22. Могильний О.М. Регулювання аграрної сфери. Ужгород : IBA, 2005. 400 с.

23. Носік В.В. Право власності на землю українського народу : монографія. Київ : Юрінком Інтер, 2006. 544 с.

24. Осовська Г.В., Юшкевич О.О., Завадський Й.С. Економічний словник. Київ : Кондор, 2007. 358 с.

25. Про засади державної регуляторної політики у сфері господарської діяльності : Закон України від 11.09.2003 р. № 1160IV. Відомості Верховної Ради України (ВВР). 2004. № 9. С. 79. URL: http://zakon2.rada.gov.ua/laws/show/1160-15.

26. Райзберг Б.А., Лозовский Л.Ш., Стародубцева Е.Б. Современный экономический словарь. 2-е изд., исправ. Москва : ИНФРА-М, 1998. 479 с. С. 356.

27. Рошер В. Система народного хозяйства. Мировая экономическая мыслль сквозь призму веков. Т. ІІІ. Ч. 1. Москва : Мысль, 2005.

28. Рябоконь В.П. Використання земельних ресурсів господарств населення в кооперативних умовах. Економіка АПК. 2009. № 3. С. 82-87.

29. Спиркин А.Г. Философия : учебник. Москва : Гардарики, 2001. 816 с.

30. Стеченко Д.М. Державне регулювання економіки : навчальний посібник. 3-тє вид., випр. Київ : Знання, 2006.262 с.

31. Струве П. Земледельческое государство. Эничикопедический словарь. Полутом 23. Санкт-Петербург : Ф.А. Брокгауз, И.А. Ефрон. С. $424-425$.

32. Федоров М.М. Економічні проблеми земельних відносин у сільському господарстві : монографія. Київ : IAE, 1998. 263 с.

33. Формування ринку землі в Україні. 2-е вид., переробл. та допов. / В.П. Галушко, Ю.Д. Білик, А.С. Даниленко та ін. ; За ред. А.С. Даниленка, Ю.Д. Білика. Київ : Урожай, 2006. 280 с.

34. Хміль Ф. І. Становлення сучасного менеджменту в Україні (проблеми теорії та практики). Львів : ЛКА, 1996. 206 с.

35. Ходаківська О.В. Екологізація аграрного виробництва : монографія. Київ : ННЦ IAE, 2015. 350 с.

36. Ходаківська О., Левек Р. Земельні відносини: пошук балансу інтересів між державним регулюванням та неолібералізмом. Економіка АПК. 2018. № 6. С. 5-17.

37. Чечетов М., Жадан I. Управління державними корпоративними правами у контексті економічної стратегії держави. Економіка України. 2003. № 8. С. 4-13.

38. Швайка Л.А. Державне регулювання економіки : навчальний посібник. Київ : Знання, 2006. 435 с.

39. Шишкин С.Н. Государственное регулирование экономики: предпринимательско-правовой аспект. Москва : Волтерс Клувер, 2007. 256 с.

40. Khodakivska O. and Mohylnyi O. The Modern State Agricultural Policy of Ukrainia: problems of countries with transition economy. Public policy and administration, 2018. Vol. 17, No. 4, pp. 526-538. URL: https://doi.org/10.13165/VPA-18-17-4-03. 
41. Khodakivska O., Mohylnyj O., Kolesnyk T., Mykhalchyshyna L., Khomyachenko S. Conformity of land relations to productive forces: retrospective analysis. EurAsian Journal of BioSciences, 2019. No. 13. Pp. 2119-2124. URL: http://www.ejobios.org/ article/conformity-of-land-relations-to-productive-forces-retrospective-analysis-7383.

\section{References:}

1. Andreytsev, V.I. (2007). Land law and legislation of sovereign Ukraine. Actual problems of practical theory. 2nd ed., Corr. Kyiv, $445 \mathrm{p}$.

2. Boyko, L.M. (2011). Regulation of land relations in agriculture: monograph. Kyiv: NSC IAE, 316 p.

3. Burov, M.P. (2008). System of regulation of economic interaction of regions: monograph. Moscow, 320 p.

4. State regulation of the market economy: textbook / ed. Kushlina V.I., Volgina N.A. 2001. Moscow, 735 p.

5. Grinova, V.M., Novikova, N.M. (2004). State regulation of the economy: a textbook. Kharkiv, 756 p.

6. Gutsulyak, G.D. (1991). Land resource potential of the Carpathian region. Lviv, 152 p.

7. Dibrova, A.D. (2008). State regulation of agricultural production: theory, methodology, practice. Kyiv, 488 p.

8. Environmental law of Ukraine. (2005). Academic course: textbook / For general. ed. Yu.S. Shemshuchenko. Kyiv, 848 p.

9. Economic encyclopedia: in 3 volumes. Vol. 3 / S.V. Mocherny (ed.) and others. 2002. Kyiv, 952 p.

10. Yermolenko, V. (2004). Land resources in property turnover. Law of Ukraine. Vol 6, pp. 43-46.

11. Zhuk, I.N. (2008). Management: dictionary-reference book. Moscow, 1024 p.

12. Zhushman, V.P. (2004). Agrarian law and legislation of Ukraine: educational practice. manual. Kharkiv, 688 p.

13. Zagorodniy, A.G., Voznyuk G.L. (2007). Financial and economic dictionary. Kyiv, 1072 p.

14. Land Code of Ukraine of 25.10.2001 No. 2768-III. (2001). Retrieved from: http://zakon4.rada.gov.ua/laws/show/2768-14.

15. History of economic doctrines (Modern economic thought): a textbook. Type 3, stereotypical / ed. Mochernogo S.V. 2007. Lviv, $488 \mathrm{p}$.

16. Kulinych, P.F. (2011). Legal problems of protection and use of agricultural lands in Ukraine: monograph. Kyiv, 688 p.

17. Kuriltsiv, R.M. (2014). The concept and essence of multifunctional land use as a paradigm of integrated land use management policy. Land management, cadastre and land monitoring. Vol. 1-2., pp. 4-10.

18. Lazor, O.D., Lazor, O.Ya. (2006). Local government: concepts, topics, definitions: Dictionary. Kyiv, 352 p.

19. Lupenko, Y.O., Kropyvko, M.F. (2013). Agroholdings in Ukraine and strengthening the social orientation of their activities. Ekonomika APK. Vol. 7. Pp. 5-20.

20. Martyniuk, M.P. (2016). Theoretical principles of regulation of land relations in Ukraine. Ekonomika APK. Vol 7. Pp. 10-15.

21. Melnyk, S.A. (2000). Management of regional economy: a textbook. Kyiv, 124 p.

22. Mohylny, O.M. (2005). Regulation of the agricultural sector. Uzhhorod, $400 \mathrm{p}$.

23. Nosik, V.V. (2006). The right of ownership of the land of the Ukrainian people: a monograph. Kyiv, $544 \mathrm{p}$.

24. Osovskaya, G.V., Yushkevich, O.O., Zavadsky, J.S. (2007). Economic dictionary. Kyiv, 2007. 358 p.

25. On the principles of state regulatory policy in the field of economy: Law of Ukraine of 11.09.2003 No. 1160-IV. (2004). Information of the Verkhovna Rada of Ukraine (VVR). Vol. 9. P. 79. Retrieved from: http://zakon2.rada.gov.ua/laws/show/1160-15.

26. Raizberg, B.A., Lozovsky, L.Sh., Starodubtseva, E.B. (1998). Modern economic dictionary. 2nd ed., Revised. Moscow, 479 p.

27. Rosher, V. (2005). System of the national economy. World economic thought through the prism of centuries. T. III. Part 1. Moscow, $246 \mathrm{p}$.

28. Ryabokon, V.P. (2009). Use of land resources of households in cooperative conditions. Ekonomika APK. Vol. 3. Pp. 82-87.

29. Spirkin, A.G. (2001). Philosophy: a textbook. Moscow, 816 p.

30. Stechenko, D.M. (2006). State regulation of the economy: textbook. 3rd ed., Ed. Kyiv, 262 p.

31. Struve, P. (2001). Agricultural state. Encyclopedic Dictionary. Polutom 23. St. Petersburg: F.A. Brockhaus, I.A. Efron. Pp. 424-425.

32. Fedorov, M.M. (1998). Economic problems of land relations in agriculture: monograph. Kyiv, 263 p.

33. Formation of the land market in Ukraine. 2nd ed., Reworked. and add. / V.P. Galushko, Yu.D. Bilyk, A.S. Danylenko and others (2006). Kyiv, 280 p.

34. Khmil, F.I. (1996). Formation of modern management in Ukraine (problems of theory and practice). Lviv, $206 \mathrm{p}$.

35. Khodakivska, O.V. (2015). Ecologization of agricultural production: monograph. Kyiv, 350 p.

36. Chechetov, M., Zhadan, I. (2003). Management of state corporate rights in the context of economic strategy of the state. Ukraine economy. Vol. 8. Pp. 4-13.

37. Shvaika, L.A. (2006). State regulation of the economy: textbook. Kyiv, $435 \mathrm{p}$.

38. Shishkin, S.N. (2007). State regulation of the economy: entrepreneurial and legal aspect. Moscow, $256 \mathrm{p}$.

39. Khodakivska O., Levek R. (2018). Land relations: the search for a balance of interests between government regulation and neoliberalism. Ekonomika APK, Vol. 6. Pp. 5-17.

40. Khodakivska, O. and Mohylnyi, O. (2018). The Modern State Agricultural Policy of Ukraine: problems of countries with transition economy. Public policy and administration. Vol. 17, No. 4, pp. 526-538. Retrieved from: https://doi.org/10.13165/ VPA-18-17-4-03.

41. Khodakivska, O., Mohylnyj, O., Kolesnyk, T., Mykhalchyshyna, L., Khomyachenko, S. (2019). Conformity of land relations to productive forces: retrospective analysis. EurAsian Journal of BioSciences, Vol. 13: 2119-2124. Retrieved from: http://www.ejobios.org/article/conformity-of-land-relations-to-productive-forces-retrospective-analysis-7383. 